\title{
Structure and Regeneration Status of Menagesha Amba Mariam Forest in Central Highlands of Shewa, Ethiopia
}

\author{
Abiyou Tilahun ${ }^{1,}$, Teshome Soromessa ${ }^{2}$, Ensermu Kelbessa ${ }^{2}$ \\ ${ }^{1}$ Department of Biology, College of Natural Science, Debre Berhan University, Debre Berhan, Ethiopia \\ ${ }^{2}$ Department of Plant Biology and Biodiversity Management, Science Faculty, Addis Ababa University, Addis Ababa, Ethiopia
}

Email address:

abiytila22@gmail.com (A. Tilahun)

\section{To cite this article:}

Abiyou Tilahun, Teshome Soromessa, Ensermu Kelbessa. Structure and Regeneration Status of Menagesha Amba Mariam Forest in Central Highlands of Shewa, Ethiopia. Agriculture, Forestry and Fisheries. Vol. 4, No. 4, 2015, pp. 184-194. doi: 10.11648/j.aff.20150404.16

\begin{abstract}
This study was conducted in Menagesha Amba Mariam Forest, a dry evergreen afromontane forest in central highlands of Ethiopia. The aim of the study was to determine vegetation structure, and regeneration status of the forest. Sixtynine sample plots $(20 \mathrm{~m} \times 20 \mathrm{~m})$ were laid following altitudinal gradient and each quadrat has a $125 \mathrm{~m}$ altitudinal drop. Herbaceous species were collected from five $(1 \mathrm{~m} \mathrm{x} 1 \mathrm{~m})$ sub-plots laid at four corners each and one at the centre of the large quadrat. All plant species found in each plot were recorded, collected, pressed and identified following Flora of Ethiopia and Eritrea. Diameter at Breast Height $(\mathrm{DBH})$ and height were measured for trees and shrubs having DBH $>2.5 \mathrm{~cm}$. The analysis of vegetation revealed that the forest possesses the highest number of $\mathrm{DBH}$, height and density of species at the lower classes. Vertical stratification revealed that most of the species in the Menagesha Amba Mariam Forest were found in the lower storey. The total density of tree stems per hectare and basal area of trees with DBH $>2.5 \mathrm{~cm}$ were $4,362.08$ and $84.17 \mathrm{~m}^{2} \mathrm{ha}^{-1}$ respectively. The total density of tree species greater than $2 \mathrm{~cm}$ and $10 \mathrm{~cm} \mathrm{DBH}$ were found to be 860.56 which is greater than those with $\mathrm{DBH}>20 \mathrm{~cm}$ (197.46). Thus, the regeneration prevalence of small individuals (seedlings and saplings) was at good condition. Menagesha Amba Mariam Forest, which is one of the remnant dry evergreen afromontane forests in central Ethiopia, is under high degree of anthropogenic impact, which needs further attention as it is quite close to the nearby towns.
\end{abstract}

Keywords: Altitudinal Gradient, Density, Dry Evergreen Afro Montane Forest, Regeneration, Structure

\section{Introduction}

Ethiopia has diverse flora and fauna in tropical Africa due to its great geographical diversity, vegetation types, soil types and diverse climatic conditions led to the emergence of habitats that are suitable for the evolution and survival of various plant and animal species (Gebre Egziabher, 1991). The vegetation of the country is very heterogeneous and has a rich endemic element. In Ethiopia, forest cover has been declining rapidly. Most of the remaining forests of the country are confined to south and south- western parts of the country (Bekele, 1993).

Loss of forest cover and biodiversity owing to humaninduced activities is a growing concern in many parts of the world including our country (Demissew, 1980). Deforestation is one of the main causes of the prevailing land degradation in Ethiopia. Some parts of northern Ethiopia that currently are bare and experience severe land degradation once had a good vegetation cover. The current rate of deforestation and loss of fertile topsoil results in massive environmental degradation
(Bekele, 1993). Many of the studies focusing on forests or vegetation of specific regions in Ethiopia (Hedberg, 1951 \& 1957; Mooney, 1963; Gilbert, 1970; Coetzee, 1978; Friis et al., 1982; Sharew, 1982; Woldu, 1985; Demissew, 1988; Uhlig, 1988; Woldu et al., 1989; Uhlig \& Uhlig, 1990; Woldu \& Backeus, 1991; Haugen, 1992; Tadesse , 1992; Bekele, 1993 and 1994; Miehe \& Miehe, 1994; Yeshitela and Bekele, 2003; Shibru and Balcha, 2004; Soromessa et. al., 2004) have been carried out. Moreover, the vegetation resources of Ethiopia, including forests, woodlands and bush lands, have been studied by several scholars (Pichi-Sermolli, 1957; von Breitenbach, 1963; Westphal, 1975; Chaffey, 1979; Gebre Egziabher, 1986, 1988; Friis, 1986; Friis and Tadese, 1990; Soromessa and Demissew, 2002) who have employed different methods of vegetation classification. Almost all the aforementioned studies have warned about the intractable loss of this natural resource (Mekuyie,2014). However, the current tree planting trends that have been started elsewhere will be a commitment to overcome deforestation of forest resources that will again have a significant impact on climate change issues. 
Even though Ethiopia is rich in biodiversity with high endemism and most of the forests provide socio-economic benefits and ecological function for longtime (Zewdie, 2007), most of its biodiversity is being now threatened, endangered and some are also locally extinct. This is due to habitat destruction and fragmentation, over exploitation of wildlife and their habitat beyond the limit of regeneration (Teketay, 2001).

Menagesha Amba Mariam (MAM) Forest is also one of these exposed forests, and there was no research carried out in the forest previously. Therefore, in order to implement appropriate forest management measures that could minimize forest losses, adequate information on factors affecting natural forest and the rate at which they cause depletion have to be obtained. Hence, the present situation of such fragile ecosystem grabs the attention and interest of researchers. Therefore, the present study is broadening its scope to assess the structural distribution together with regeneration status of the forest. Hence, this study was initiated to be conducted on the forest with the major objective of investigating structure and regeneration status of Menagesha Amba Mariam Forest in central highlands of Shewa, Ethiopia.

\section{Materials and Methods}

\subsection{Study Area Description}

The present study was conducted in Welmera Wereda, Oromia National Regional State, central high lands of Ethiopia (Fig. 1). The study forest is located at about $30 \mathrm{~km}$ west of Addis Ababa, and has total area around 84.354 hectare. The forest is known to have gradient of altitude and is situated approximately between $9^{0} 01^{\prime}-09^{0} 03^{\prime} \mathrm{N}$ and $38^{0} 35^{\prime}$ $-38^{0} 36^{\prime} \mathrm{E}$. The altitudinal range of the study area varies from 2574 - $2948 \mathrm{~m}$ above sea level.

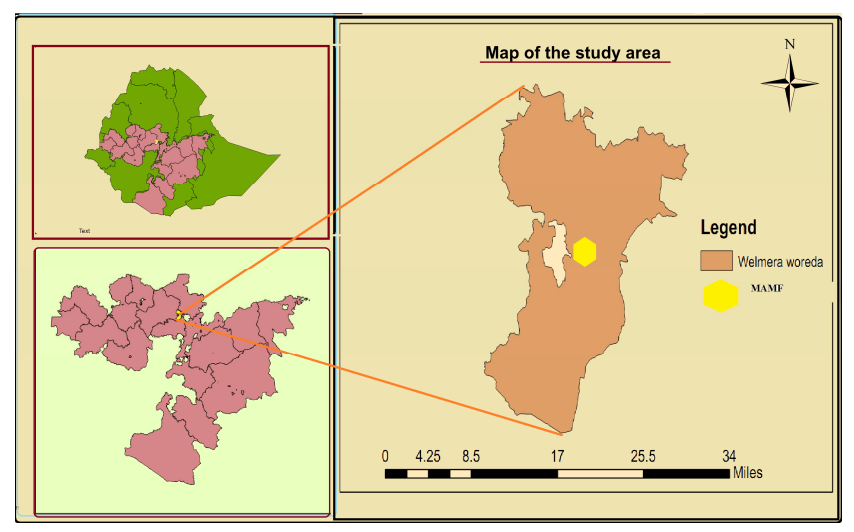

Figure 1. Location map of the study forest.

\subsection{Reconnaissance Survey, Sampling Design and Sampling}

Initially reconnaissance survey was conducted in October, 2008 in order to identify the possible sampling sites and number of transect lines to be laid across the forest and the altitudinal range of the forest area was determined.
Systematic sampling was used for the study. Sampling sites from the forest were arranged octagonally by eight line transects from the peak of the mountain to all directions covering the whole range of altitudes. Eight transects were laid at $200 \mathrm{~m}$ interval at the peak, $550 \mathrm{~m}$ at the middle of the mountain and $1.5 \mathrm{~km}$ at the bottom. The transect lines radiate from the top of the mountain to eight directions and each of them contains different number of plots depend on the length of transect. This is because the study area has a shape like Frustum of a cone. Quadrats of $20 \mathrm{~m}$ x $20 \mathrm{~m}$ (400 m ) were placed at $125 \mathrm{~m}$ altitudinal drop between each quadrat and five sub-plots $(1 \mathrm{~m} \times 1 \mathrm{~m})$ within each corner and one at the centre of the main plot for herbaceous plants were used to gather vegetation data (van der Maarel, 1979). Transects were placed on the ground using the Magellan NAV5000 Pro GPS navigation system. Sixty-nine Sample plots (2.76 ha) of each $400 \mathrm{~m}^{2}$ were laid at every $125 \mathrm{~m}$ drop in altitude in the study site.

Altitude and geographical coordinates were measured for each sample plot using 'Pretel' digital altimeter, and Magellan NAV5000 Pro GPS respectively. Then a complete list of herbs, shrubs, lianas, epiphytes, and trees were made in each plot. Plant speciemens were collected, pressed, dried,identified, and checked at the National Herbarium of the Addis Ababa University using specimens in the Herbarium and published volumes of Flora of Ethiopia and Eritrea.

\subsection{Structural Data Analysis}

All individuals of trees and shrubs with a Diameter at Breast Height $(\mathrm{DBH})$ greater than $2.5 \mathrm{~cm}$, and height greater than $1 \mathrm{~m}$ were measured for DBH. Individuals were counted as seedlings (height $\leq 1 \mathrm{~m}$ and $\mathrm{DBH} \leq 2 \mathrm{~cm}$ ) and saplings (height $>1 \mathrm{~m}$ and $\mathrm{DBH} \leq 2 \mathrm{~cm}$ ).

\subsubsection{Density}

Density is defined as the number of plants of a certain species per unit area. Tree density was computed by converting the count from the total quadrats in the hectare basis (Mueller-Dombois and Ellenberg, 1974).

\subsubsection{Basal Area (BA)}

Basal area calculations were made on the diameter measurements of the stem with DBH of $>2.5 \mathrm{~cm}$ and above. It is expressed in square centimeter/ hectare $\left(\mathrm{cm}^{2} / \mathrm{ha}\right)$ (Hutchings, 1986; Mueller-Dombois and Ellenberg, 1974). There is direct relationship between $\mathrm{DBH}$ and basal area. Basal area $(B A)=\pi(d / 2)^{2}$, where $d=D B H . \Rightarrow / C$, where C $=$ circumference, $\mathrm{d}=$ diameter

\subsubsection{Frequency}

Frequency is defined as the proportion of sample quadrats in which individuals of a species are recorded. It is obtained by using quadrats and expressed as the number of quadrats occupied by a given species per number thrown or, more often, as a percentage (Goldsmith et al., 1986). Frequency measure indicates the uniformity of the distribution of the species in the study area, which again tells about the habitat 
preference of the species (Silvertown and Doust, 1993; cited in Eshete et al., 2005). It gives an approximate indication of the homogeneity of the stand under consideration (Kent and Coker, 1992). The higher the frequency, the more important the plant is in the community (Denu, 2007). A better idea of the importance of species with the frequency can be obtained by comparing the frequency of occurrence of the entire tree species present. High frequency value shows that the plant is widely distributed in the study area but abundance does not always indicate the importance of a plant community.

\subsubsection{Importance Value Index (IVI)}

The Important Value Index (IVI) permits a comparison of species in a given forest and depicts the sociological structure of a population in its totality in the community. It often reflects the extent of the dominance, occurrence and abundance of a given species in relation to other associated species in an area (Kent and Coker, 1992). Importance Value Index (IVI) $=\mathrm{RD}+\mathrm{RF}+\mathrm{RDO}$, Where $\mathrm{RD}$ is Relative density, RF is Relative frequency and RDO as Relative Dominance.

\subsection{Diversity Indices}

\subsubsection{Shannon Wiener Diversity Index}

Shannon-Wiener (Shannon and Wiener, 1949) index is the most applicable index of diversity (Greig-Smith, 1983). Like Simpson's index, Shannon's index accounts for both abundance and evenness of species present.

\subsubsection{Simpson's Index (D)}

Simpson's index measures the probability that two individuals randomly selected from a sample will belong to the same species. It is an index of dominance and hence inversely related to evenness and richness. It is often expressed as diversity index. Simpson's index can be calculated by the formula $\mathrm{D}=(1-\lambda)$, where $\lambda=\mathrm{pi}^{2}$. The value of $\mathrm{D}$ ranges between 0 and 1 . With this index, 0 represents infinite diversity and 1 , no diversity. The similarity index used was Sorensen's similarity coefficient $(\mathrm{SI})=2 \mathrm{a} / 2 \mathrm{a}+\mathrm{b}+$ $\mathrm{c}$; where "a" is the number of common species, "b" is number of species in vegetation of one site and "c" is number of species in vegetation of another site (Kent and Coker, 1992). Jaccard's coefficient $\left(S_{J}\right)$ was also used for assessing the similarity among plant species clusters in terms of species composition. It is calculated by the formula $\left(S_{J}=a /\right.$ $a+b+c)$ where " $S_{J}$ " is Jaccard's similarity coefficient, " $a$ " is number of common species to the compared clusters , "b" is number of species in one cluster and "c" is number of species in the other cluster.

\section{Results and Discussions}

\subsection{Analysis of Vegetation Structure}

\subsubsection{Density of Tree Species}

Analysis on density distributions by diameter classes for tree species showed different patterns. Such patterns of species population structure can indicate variation in population dynamics. To observe regeneration of species in the study area, 32 plant species were selected based on their mean cover abundance value.

The total density of mature species with $\mathrm{DBH}>2.5 \mathrm{~cm}$ in the forest was 1058.02 stems $^{-1}$. This was classified into seven density classes: 1) $\leq 1$, 2) 1.01- 5, 3) 5.01-10, 4) 10.0120, 5) $20.01-35$, 6) $35.01-50$ and 7) $>50$ stems ha $^{-1}$. The density of each species was calculated and compared as the number of individuals per hectare with DBH greater than 2 $\mathrm{cm}, 10 \mathrm{~cm}$ and $20 \mathrm{~cm}$ (Table 1). The density of trees with DBH greater than $2 \mathrm{~cm}$ is 705.1 individuals / ha.

Table 1. Distribution of trees in different DBH classes.

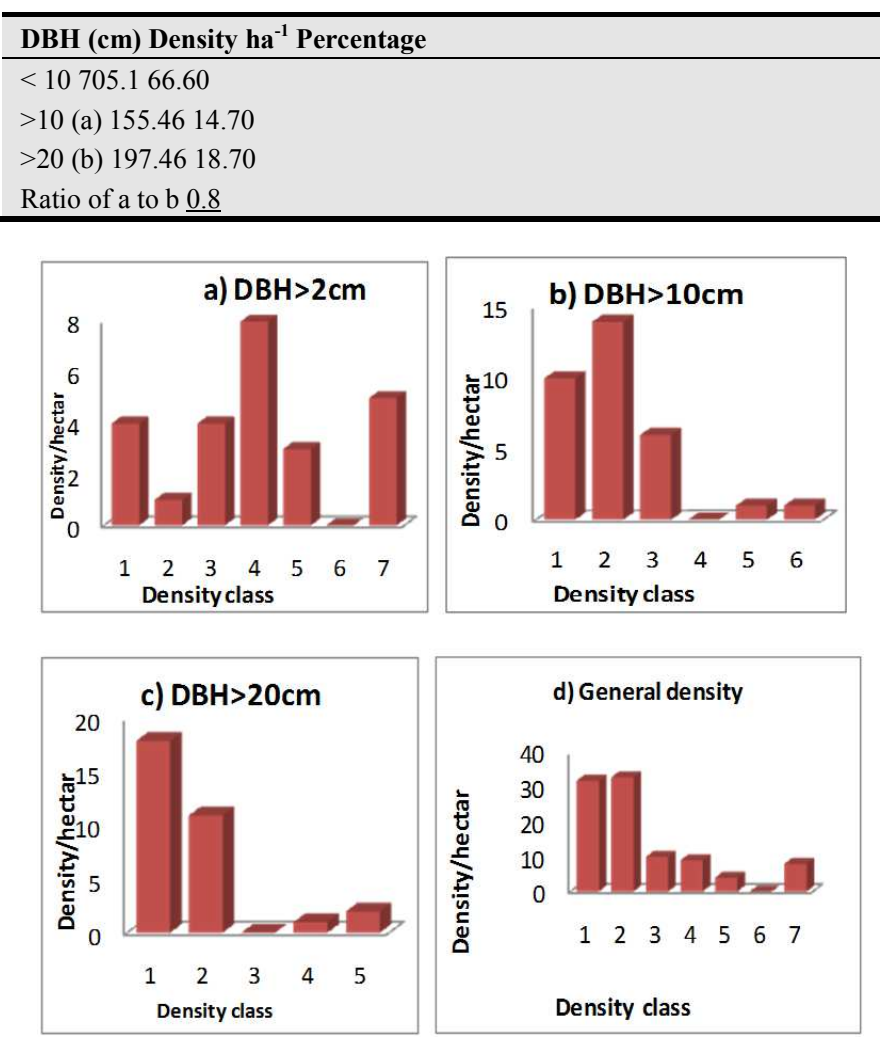

Figure 2. Population structure of plant species with $\mathrm{DBH}>2 \mathrm{~cm},>10$ $\mathrm{cm},>20 \mathrm{~cm}$ and their general density.

The density shows irregular distribution which increases from the first to the second classes and then decrease in the third class and then increase in the fourth; it also decreases in the fifth class and absent in the sixth class (Fig.2a). The density of species with DBH greater than $10 \mathrm{~cm}$ is 155.46 individuals per hectare. This class shows significant values in the first three classes and very small values in the fifth and seventh classes and totally absent in the fourth and sixth classes (Fig.2b). The density of woody species at DBH greater than $20 \mathrm{~cm}$ is 197.46 individuals per hectare. The first two classes contain maximum values of this class while the fourth and seventh classes show very small values and classes: three, five and six have no representatives (Fig. 2c).

The overall density distribution of the forest shows high value in the first two classes and small values in the rest classes except class six, which has no representatives in all 
the density classes (Fig. 2d). As Table 2 shows, the largest proportion of the species density at $\mathrm{DBH}>2 \mathrm{~cm}$ is contributed by Olea europaea (17.7\%) followed by Juniperus procera (15.8\%) Olinia rochetiana $(11.3 \%)$ and Erica arborea $(9.73 \%)$ which constitute the $1^{\text {st }}, 2 \mathrm{nd}, 3^{\text {rd }}$ and $4^{\text {th }}$ largest proportions. The density of species (Table 3 ) at the DBH class $>10 \mathrm{~cm}$ alone is 155.46 individuals per hectare.
At this DBH class, the largest proportion of species density is contributed by Juniperus procera (34.00\%), Olea europaea subsp. cuspidata (20.5\%) and Myrica salicifolia (5.1\%). Tree species with DBH class $>20 \mathrm{~cm}$ has 197.46 individuals ha ${ }^{-1}$. Among the tree species Juniperus procera, Olea europaea subsp. cuspidata and Scolopea theifolia covers $50.8 \%$, $25.5 \%$, and $9 \%$ of the species density respectively.

Table 2. Density ha-1 of seedling, sapling and mature tree species in Menagesha Amba Mariam Forest.

\begin{tabular}{|c|c|c|c|c|c|c|}
\hline No & Botanical name & Habit & Seedling Density ha ${ }^{-1}$ & Sapling Density ha ${ }^{-1}$ & Tree D ha ${ }^{-1}$ & Sum of densities \\
\hline 1 & Acacia abyssinica & $\mathrm{T}$ & 14.13 & 27.9 & 68.12 & 110.15 \\
\hline 2 & Apodytes dimidiata & $\mathrm{T}$ & 0 & 0 & 3.62 & 3.62 \\
\hline 3 & Arundinaria alpina & S & 1.5 & 11.23 & 15.22 & 27.95 \\
\hline 4 & Bersama abyssinica & $\mathrm{T}$ & 30.1 & 19.6 & 65.94 & 115.64 \\
\hline 5 & Buddleja polystachya & $\mathrm{T}$ & 5.44 & 0.72 & 20.65 & 26.81 \\
\hline 6 & Carissa spinarum & S & 22.5 & 8 & 189.86 & 220.36 \\
\hline 7 & Croton macrostachyus & $\mathrm{T}$ & 1.1 & 2.54 & 7.97 & 11.61 \\
\hline 8 & Podocarpus falcatus & $\mathrm{T}$ & 36.23 & 32.25 & 92.39 & 160.87 \\
\hline 9 & Dombeya tórrida & $\mathrm{T}$ & 6.9 & 14.5 & 26.45 & 47.85 \\
\hline 10 & Dovyalis abyssinica & $\mathrm{T}$ & 15.6 & 23.2 & 78.62 & 117.42 \\
\hline 11 & Ekebergia capensis & $\mathrm{T}$ & 0.36 & 4.4 & 8.33 & 13.09 \\
\hline 12 & Erica arborea & $\mathrm{T}$ & 68.5 & 117 & 260.51 & 446.01 \\
\hline 13 & Ficus sur & $\mathrm{T}$ & 0.36 & 145.1 & 6.52 & 151.98 \\
\hline 14 & Hagenia abyssinica & $\mathrm{T}$ & 0.72 & 3.3 & 17.39 & 21.41 \\
\hline 15 & Hypericum revolutum & $\mathrm{T}$ & 8.33 & 23.6 & 35.14 & 67.07 \\
\hline 16 & Juniperus procera & $\mathrm{T}$ & 19.2 & 81.5 & 365.22 & 465.92 \\
\hline 17 & Maesa lanceolata & $\mathrm{T}$ & 1.1 & 6.2 & 7.97 & 15.27 \\
\hline 18 & Maytenus arbutifolia & $\mathrm{T}$ & 4.7 & 19.2 & 37.32 & 61.22 \\
\hline 19 & Maytenus obscura & $\mathrm{T}$ & 3.62 & 2.17 & 12.68 & 18.47 \\
\hline 20 & Millettia ferruginia & $\mathrm{T}$ & 0 & 1.1 & 2.17 & 3.27 \\
\hline 21 & Myrica salicifolia & $\mathrm{T}$ & 8.7 & 8 & 34.06 & 50.76 \\
\hline 22 & Nuxia congesta & $\mathrm{T}$ & 6.2 & 48.6 & 87.32 & 142.12 \\
\hline 23 & Olea europaea subsp. cuspidata & $\mathrm{T}$ & 31.9 & 146.4 & 385.14 & 563.44 \\
\hline 24 & Olinia rochetiana & $\mathrm{T}$ & 79.7 & 133.3 & 297.46 & 510.46 \\
\hline 25 & Osyris quadripartita & $\mathrm{T}$ & 8.7 & 21.7 & 112.32 & 142.72 \\
\hline 26 & Pittosporum viridiflorum & $\mathrm{T}$ & 11.6 & 56.9 & 81.16 & 149.66 \\
\hline 27 & Scolopia theifolia & $\mathrm{T}$ & 5.44 & 18.5 & 46.01 & 69.95 \\
\hline 28 & Prunus africanus & $\mathrm{T}$ & 13.8 & 40.6 & 72.1 & 126.5 \\
\hline 29 & Rhamnus staddo & $\mathrm{T}$ & 1.8 & 0.72 & 6.52 & 9.04 \\
\hline 30 & Rhus glutinosa & $\mathrm{T}$ & 5.44 & 22.1 & 29.35 & 56.89 \\
\hline 31 & Rhus vulgaris & $\mathrm{T}$ & 30 & 60.9 & 128.26 & 219.16 \\
\hline \multirow[t]{2}{*}{32} & Sideroxylon oxyacanthum & $\mathrm{T}$ & 8.1 & 64.9 & 142.39 & 215.39 \\
\hline & Total & & 451.77 & 1166.13 & 2744.18 & 4362.08 \\
\hline
\end{tabular}

The ratio of the density of individuals greater than $10 \mathrm{~cm}$ to those greater than $20 \mathrm{~cm}$ is taken as a measure of the distribution of the size classes (Grub et al., 1963). This ratio is 0.8 for the Menagesha Amba Mariam Forest, indicating 
only slight variability between the proportion of small-sized and large-sized individuals.

According to Grubb et al. (1963), the ratio of 'density at DBH class $>10 \mathrm{~cm}$ ' to 'density at DBH class $>20 \mathrm{~cm}$ ' can be used as a measure of the distribution of the different size classes. The dominance of small sized $(\mathrm{DBH}>2-9.9 \mathrm{~cm})$ individuals in the forest is largely due to the high density of Olea europaea subsp. cuspidata (124.28 stems/ha), Juniperus procera $(111.23 \mathrm{stem} / \mathrm{ha})$, Olinia rochetiana (79.71 stems ha $\left.{ }^{-1}\right)$ and Erica arborea $(68.5 \mathrm{stems} / \mathrm{ha})$ (Table 2).

\subsubsection{Diameter at Breast Height (DBH)}

The distribution of trees in different DBH classes is given in Figure 3. The number of stems in DBH class less than 10 $\mathrm{cm}$ (classes 1 and 2) is 708.7/ha (67.18\%), 188.04/ha (17.8\%) in $10-25 \mathrm{~cm}, 89.13 / \mathrm{ha}(8.42 \%)$ in $25-40 \mathrm{~cm}$ and $69.93 / \mathrm{ha}$ $(6.6 \%)$ in $>40 \mathrm{~cm}$. The overall density distribution of individuals in the various size classes showed decline towards the higher DBH classes (i.e., as DBH size classes increase the number of individuals decrease). The highest densities of species were recorded in the lowest DBH size classes. The distribution of trees in DBH class from lower to higher showed a decreasing trend, but the percentage DBH of trees in DBH class $>140 \mathrm{~cm}$ was contributed by Juniperus procera, Olea europaea subsp. cuspidata and few individuals of Hagenia abyssinica. The total DBH of trees in lower classes is much higher when compared to the DBH of the intermediate and higher classes. Distribution of all individuals in different size classes showed relatively an inverted J-shape distribution for both DBH and height classes (Fig. 3). This pattern indicates that the majority of the species had the highest number of individuals in lower DBH and height classes. This pattern implies that the forest vegetation has good reproduction and recruitment potential.
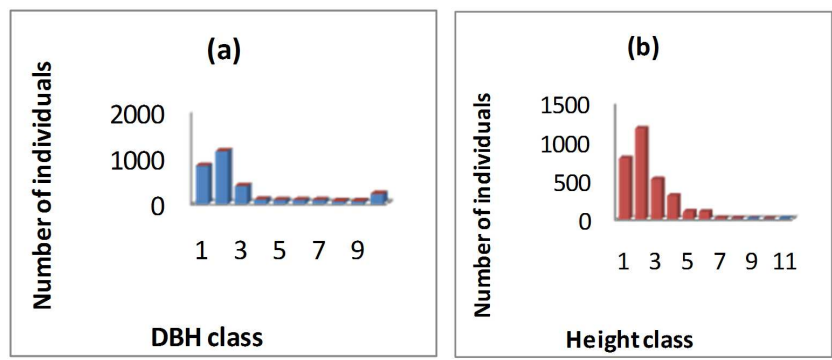

Figure 3. General DBH and Height class versus number of individuals in MAM Forest.

Analysis of density distribution by diameter classes of woody species resulted in different patterns (Figure 4a-j). The first pattern shows high value in the $5.1-10 \mathrm{~cm}$ diameter class and almost uniformly represented in the rest classes. This pattern is detected for Juniperus procera (Fig.4a). Figure $4 \mathrm{c}, \mathrm{d}$, and $\mathrm{g}$ also showed strong peaks up to $10 \mathrm{~cm}$ and followed by abrupt decline from $10.1-20 \mathrm{~cm}$ and then totally absent in the higher classes $(>20 \mathrm{~cm})$. This pattern was represented by Erica arborea, Osyris quadripartita, and Rhus vulgaris. Population patterns (Figure $4 \mathrm{e} \& \mathrm{j}$ ) indicating selective removal of higher-class individuals which shows good reproduction but, discontinuous recruitment. Representative species for this pattern are Prunus africana and Acacia abyssinica.
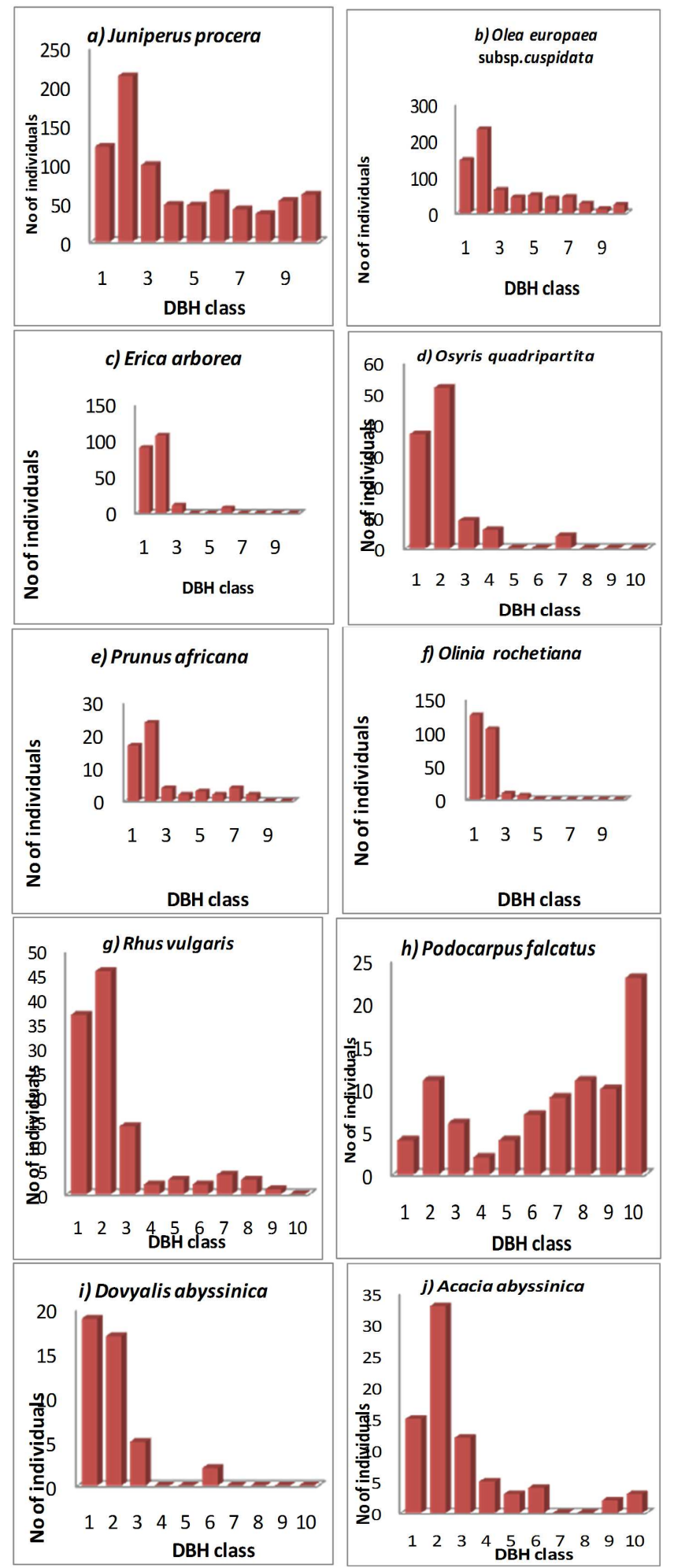

Figure 4. (a-j). Top dominant tree species population structure of the Forest.

Figure $4 \mathrm{~b}$ shows high value up to $10 \mathrm{~cm}$ (class1 \& 2) and uniformly decline up to the ninth class and also increases in 
the tenth class. This pattern relatively shows an inverted Jshape and exemplified by Olea europaea subsp. cuspidata. The other recognizable pattern (Figure $4 \mathrm{~h}$ ) shows high value in the higher DBH classes and small value in DBH classes $<5$ $\mathrm{cm}$, and $15-25 \mathrm{~cm}$ and then highest value in the last class $(>45 \mathrm{~cm})$. This pattern revealed selective cutting and removal of medium sized individuals have taken place. In this case, the juveniles are not well represented and show poor regeneration. The representative example is Podocarpus falcatus.

\subsubsection{Tree Height}

The trees in the study area could be conveniently divided into eleven height classes. The overall height class distribution of individuals in Menagesha Amba Mariam Forest showed higher number of individuals in the lower size and a gradual decrease towards the middle and upper size trees indicating continuous representation of individuals in all height classes. Trees in height class I and II, together make $65.5 \% /$ ha. Trees in the height classes III and IV together are found to be $24.5 \%$. The old trees are found in the height class VII and VIII and their percentage distribution is 9.52\%/ha. Height classes I and II are represented by Olea europaea subsp. cuspidata, Juniperus procera, Erica arborea, Sideroxylon oxyacanthum with $15.78 \%, 15,6 \%, 9.91 \%$ and $8.8 \%$ respectively while height class VIII is dominated by Juniperus procera $(72 . .7 \%)$ and Apodytes dimidiata $(27.27 \%)$. The upper canopy is dominated by these five tree species in the area. Olea europaea subsp. cuspidata, Juniperus procera, and Prunus africana are the emergent trees and grow above all the canopy trees except Podocarpus falcatus and Hagenia abyssinica at some inaccessible and well protected parts of the forest. The analysis based on relative density, diameter and height classes carried out for tree species of the forest resulted in different patterns. Generally, four patterns of population structure were analyzed. Each structural pattern reveals different population dynamics (Fig. 5 a-j).

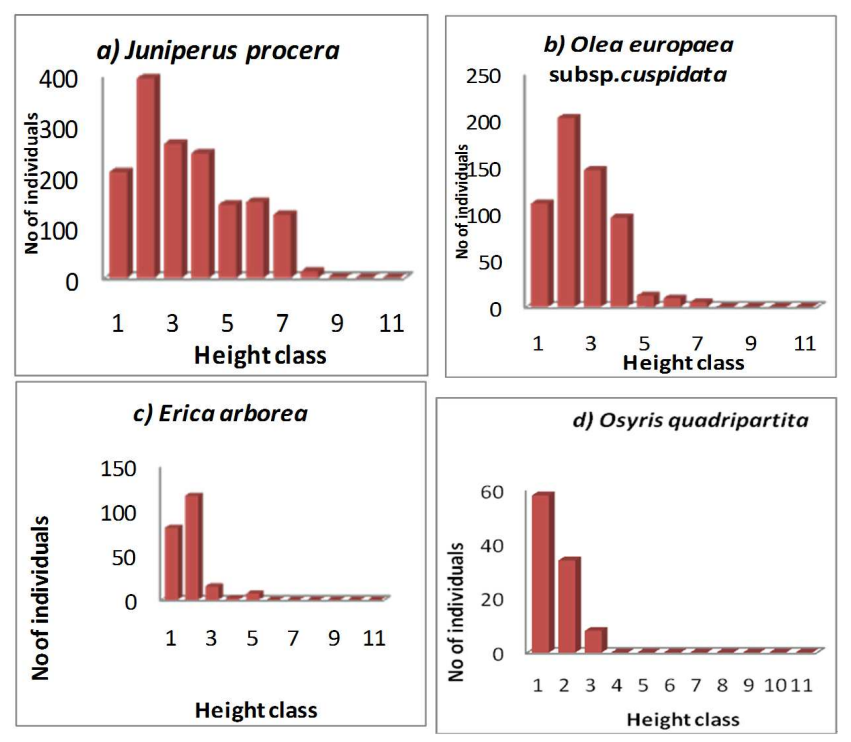

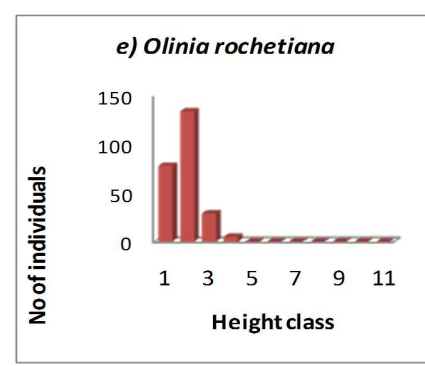
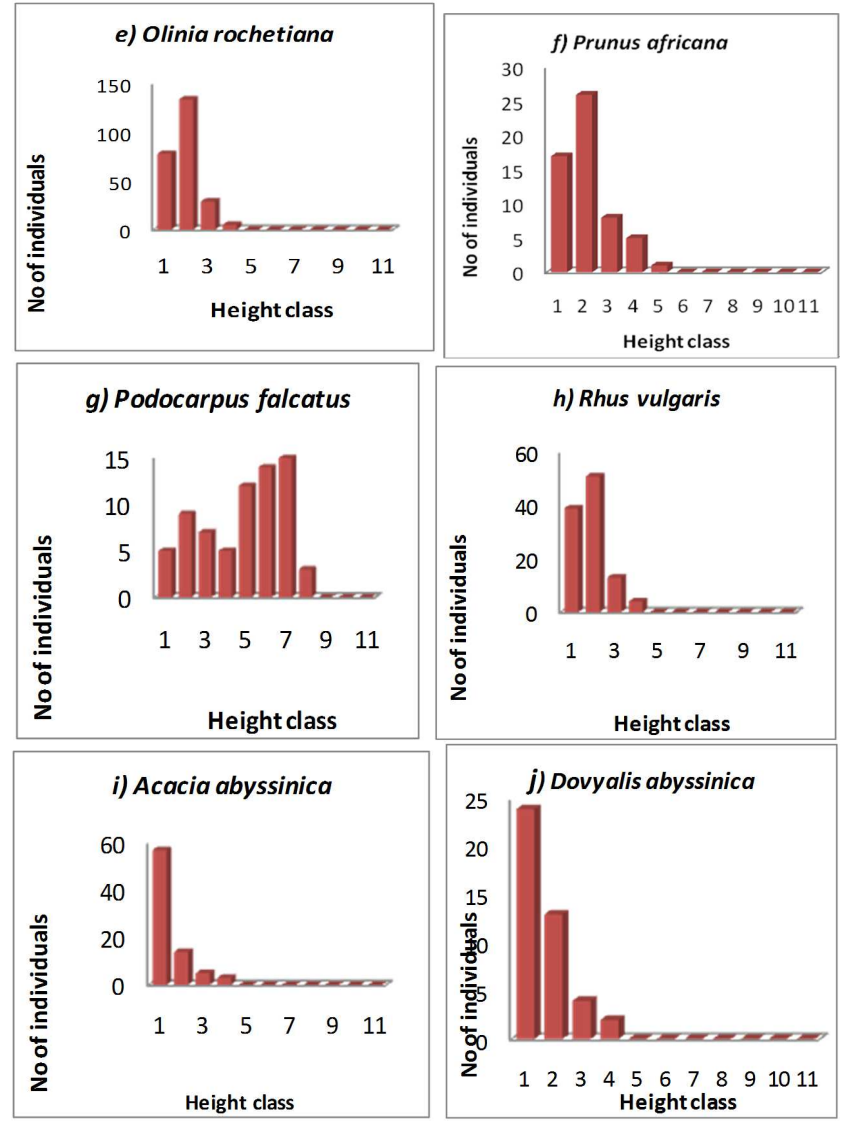

Figure 5. (a-j). Top dominant tree species population structure of MAMForest.

The first pattern was formed by species with highest density in the second-class, medium value in the first, third and fourth classes, small values in classes five six and seven and no value in the rest classes. This pattern shows better reproduction but a bad recruitment potential in the forest. This pattern was observed height class of Olea europaea subsp. cuspidata and Juniperus procera (Fig. 5a \& b).

The second pattern (Fig. 5c, e, f \& h) was indicated by species well represented in the lower height classes and absent in the higher classes which are species with no reproduction and only very few large and old individuals. This pattern was frequent in most shrubs and some trees. This indicates that there is an indiscriminate exploitation of large individuals of this species. Species with such a pattern could become endangered in the future, because individuals are being harvested before reaching reproductive ages, and this could result in the future decline of the species population because these reflect good reproduction but, bad recruitment. The height class of Erica arborea, Olinia rochetiana, Prunus africana and Rhus vulgaris shows this type of pattern.

The third pattern (Fig. 5j) indicates a normal distribution of species with reversed J-shape. Maximum values occurred in the first class and then reduce gradually up to the fourth class. This pattern represents good reproduction status and regeneration potential. Osyris quadripartita is the representative of this pattern. 
The fourth pattern was indicated by low density in the lower height classes and high density in the higher height classes and no value in the last class. The species under this pattern have big individuals that are less competent to reproduce and hence represent poor reproduction, regeneration and thus a declining population. The pattern shows relatively J-shape curve and represented by height class of Podocarpus falcatus (Fig. 5g).

Variations in the population structure of plant species may be attributed to environmental factors that can interrupt in regeneration, differences in the regeneration behavior of the species, human intervention, and change in climate, natural and artificial disturbances.

\subsection{Vertical Structure}

According to this scheme, three simplified vertical structures are distinguished in tropical forests. These are upper, middle and lower storeys. Based on the above scheme the forest vegetation was classified into three strata. The upper includes where individual tree height exceeds $2 / 3$ of the top height while the middle storey includes species having height between $1 / 3$ and $2 / 3$ of the top height and the lower stratum (storey) is less than $1 / 3$ of the top height(Lamprecht, 1989). Based on the result obtained from the study the top height is $30 \mathrm{~m}$, which indicates that the upper storey is greater than $20 \mathrm{~m}$, the middle storey is between $10 \& 20 \mathrm{~m}$ and the lower storey is less than $10 \mathrm{~m}$. The result obtained from this forest study indicated that the highest species density, 192 species $(86.5 \%)$ was found in the lower storey. Most of the apparent gaps were filled up with under storey species canopy. The lower storey is mainly covered with herbs, shrubs and small trees (Figure 6). Twenty-five species of plants $(11.5 \%)$ reach to the middle storey. Species like Erica arborea, Olinia rochetiana, Croton macrostachyus, Hagenia abyssinica, Buddleja polystachya, Bersama abyssinica, Nuxia congesta, Osyris quadripartita, Ficus sur, Acacia abyssinica, Maytenus arbutifolia, Maytenus obscura, Dovyalis abyssinica, Pittosporum viridiflorum, Prunus africana, Rhus vulgaris, Rhus glutinosa, Sideroxylon oxyacanthum, Myrica salicifolia, Acacia mearnsii, Dombeya torrida, Arundinaria alpina, Scolopia theifolia, Pinus patula, and Eucalyptus globulus have representatives in the middle storey. The Upper storey also contains Only 5 emergent tree species $(2.3 \%)$ of the total individuals in the forest that include Podocarpus falcatus, Juniperus procera, Olea europaea subsp. cuspidata, Apodytes dimidiata and Millettia ferruginea. There are many species, which could not attain the upper and the middle storey by their nature. All species that have representative in the upper also appeared in the middle and lower storey. Most of these trees have started dying-back from their tips and degenerating and some of them are completely absent.

\subsubsection{Basal Area (BA)}

The basal area of Menagesha Amba Mariam Forest was $84.17 \mathrm{~m}^{2} /$ ha. The highest $(44.38 \%)$ and the lowest $(0.01 \%)$ BA ha ${ }^{-1}$ was contributed by Juniperus procera and Maesa lanceolata respectively. It is important to note here that species with the highest basal area do not necessarily have the highest density, indicating size difference between species (Bekele, 1994; Shibru and Balcha, 2004; Denu, 2007). It was reported that BA provides a better measure of the relative importance of the species than simple stem count (Cain and Castro, 1959; cited in Bekele, 1994). Thus, species with the largest contribution to BA can be considered as the most important species in the forest. Consequently, the most important tree species in Menagesha Amba Mariam Forest are Acacia abyssinica, Hagenia abyssinica, Olea europaea subsp. cuspidata, Juniperus procera, Podocarpus falcatus and Rhus vulgaris.

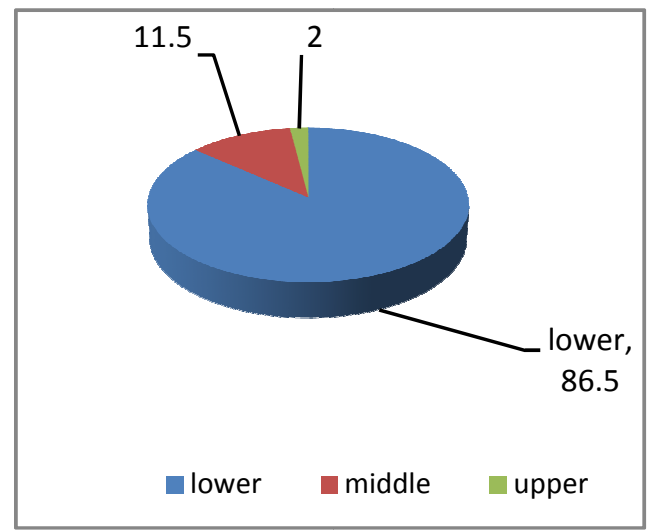

Figure 6. Percentage density of trees in lower, middle and upper storey.

\subsubsection{Frequency}

The trees and shrubs were classified into five frequency classes on the bases of their percentage frequency values: $1=$ $0-20,2=21-40,3=41-60,4=61-80$ and $5=>81$. Two tree species (Olea europaea subsp. cuspidata, Juniperus procera) are most frequently occurred (in 68 and 66 quadrats out of 69) respectively. The species with more than $50 \%$ distribution were Carissa spinarum, Dovyalis abyssinica, Erica arborea, Nuxia congesta, Rhus vulgaris, Olinia rochetiana, Osyris quadripartita and Pittosporum viridiflorum. The species with the least occurrence are Aruninaria alpina, Apodytes dimidiata, Ekebergia capensis, Millettia ferruginea, Rhamnus staddo, Hagenia abyssinica and Ficus sur. This study revealed that there is high frequency in the lower frequency classes and low frequency in the higher frequency classes. This indicates that the vegetation has high heterogeneity and low homogeneity.

\subsubsection{Importance Value Index (IVI)}

Importance Value Index combines data from three parameters, which include RF, RD and RDO (Kent and Coker, 1992). IVI is useful to compare the ecological significance of species (Lamprecht, 1989). It was also stated that species with the greatest importance value are the leading dominant species of specified vegetation (Shibru and Balcha, 2004). Percentages of species in the IVI classes were $32.5 \%, 9.8 \%, 28.6 \%, 27.6 \%$ and $1.5 \%$ for classes $1,2,3,4$, and 5 respectively (Table 4 ). 
Table 3. IVI classes, values, sum of species belonging to each class and their percentage value.

\begin{tabular}{llll}
\hline IVI class \&value & No of species & Sum of IVI & Percentage (\%) \\
\hline $5(<1)$ & 6 & 4.22 & 1.5 \\
$4(1-10)$ & 17 & 82.93 & 27.6 \\
$3(10.1-20)$ & 6 & 85.73 & 28.6 \\
$2(20.1-30)$ & 1 & 29.52 & 9.8 \\
$1(>30)$ & 2 & 97.6 & 32.5 \\
\hline
\end{tabular}

The highest IVI value (88.7\%) was in classes 1,3 and 4, while the remaining (11.3\%) at classes 2 and 5 (Figure 7). The five most dominant tree species of Menagesha Amba Mariam Forest occupied $54.5 \%$ of the total important value index (Table 3). The dominant species were Erica arborea, Olinia rochetiana, Podocarpus falcatus, Olea europaea subsp. cuspidata and Juniperus procera. Figure 7 shows that much of IVI was attributed by a few species. These tree individuals were tolerant species that resist high pressure of disturbance, natural and environmental factors, and the effect of local communities.

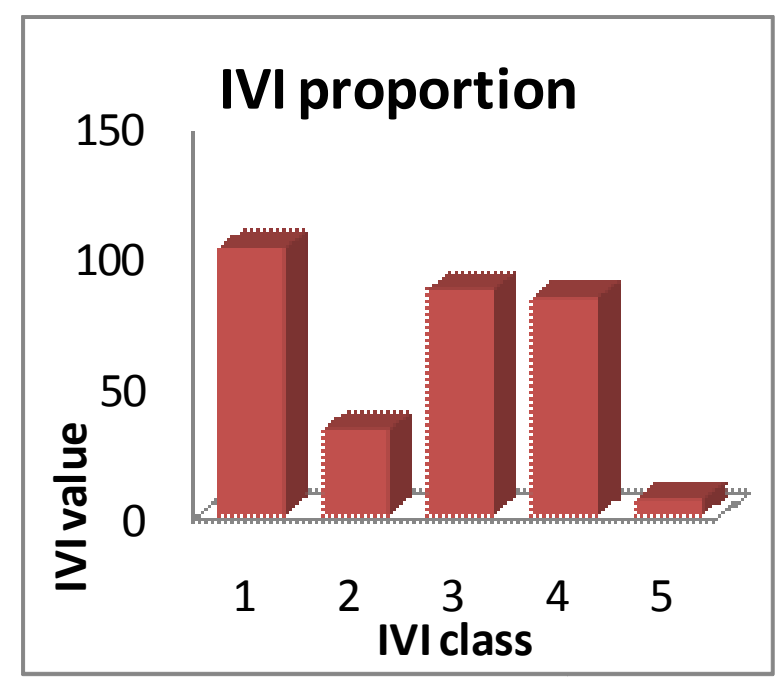

Figure 7. The IVI proportions of most frequent and dominant trees and shrubs in the study area, IVI class: $1=>30,2=20.1-30,3=10.1-20,4=1-10$, $5=<1$.

In terms of abundance, distribution and basal area, the contribution of Olea europaea subsp. cuspidata and Juniperus procera were the highest of all tree species and accounted for $32.53 \%$. These two species were the most frequent $(16.9 \%)$ and they had the highest BA $\left(59.7 \mathrm{~m}^{2} \mathrm{ha}^{-1}\right)$ out of the total BA $\left(84.17 \mathrm{~m}^{2} \mathrm{ha}^{-1}\right)$. Millettia ferruginea and Ekebergia capensis had the lowest relative IVI values and were found to be the least dominant species among the species in the study site. Juniperus procera was 150 times more important than Millettia ferruginea. Similarly, Olea europaea subsp. cuspidata was 75 times more important than Ekebergia capensis in Forest. Priority for conservation of these species must be given based on their IVI values (i.e. the first priority for species with highest IVI value and the last priority of conservation for species with least IVI values) (Table 3). The result in Table 4 shows three species
(Juniperus procera, Olea europaea subsp. cuspidata and Podocarpus falcatus are grouped in priority class one that require immediate conservation and protection while species like Millettia ferruginea, Ekebergia. capensis, Rhamnus staddo, Apodytes dimidiata , Maeasa lanceolata and Arundinaria alpina in the last priority class and they need the last priority of conservation. The rest of the species are in the intermediate priority classes (2, 3 and 4), indicating that they need intermediate conservation programme.

\subsection{Regeneration Status of Some Woody Species}

The density and composition of seedlings and saplings indicate the status of regeneration. The total density of seedling, sapling and trees were $451.77 \mathrm{ha}^{-1}, 1166.13 \mathrm{ha}^{-1}$ and $2744.18 \mathrm{ha}^{-1}$. The ratio of seedlings to saplings is 0.4 and saplings to trees $(0.43)$ and seedlings to mature trees is 0.17 . The above ratio indicates that the distribution of seedling populations less than that of sapling and that of saplings is less than mature individuals (i.e. density of seedling $<$ saplings $<$ mature trees). The distribution of seedlings, saplings and mature trees shows three distinct patterns.

First distribution pattern contains least density of seedlings, intermediate in saplings and highest in the tree levels. This pattern was exhibited by Hagenia abyssinica, Olea europaea subsp. cuspidata, Juniperus procera, Osyris quadripartita, Pittosporum viridiflorum, Scolopia theifolia, Prunus africana, Dovyalis abyssinica, Ekebergia capensis, Rhus glutinosa, Rhus vulgaris and Sideroxylon oxyacanthum (Fig.8a).
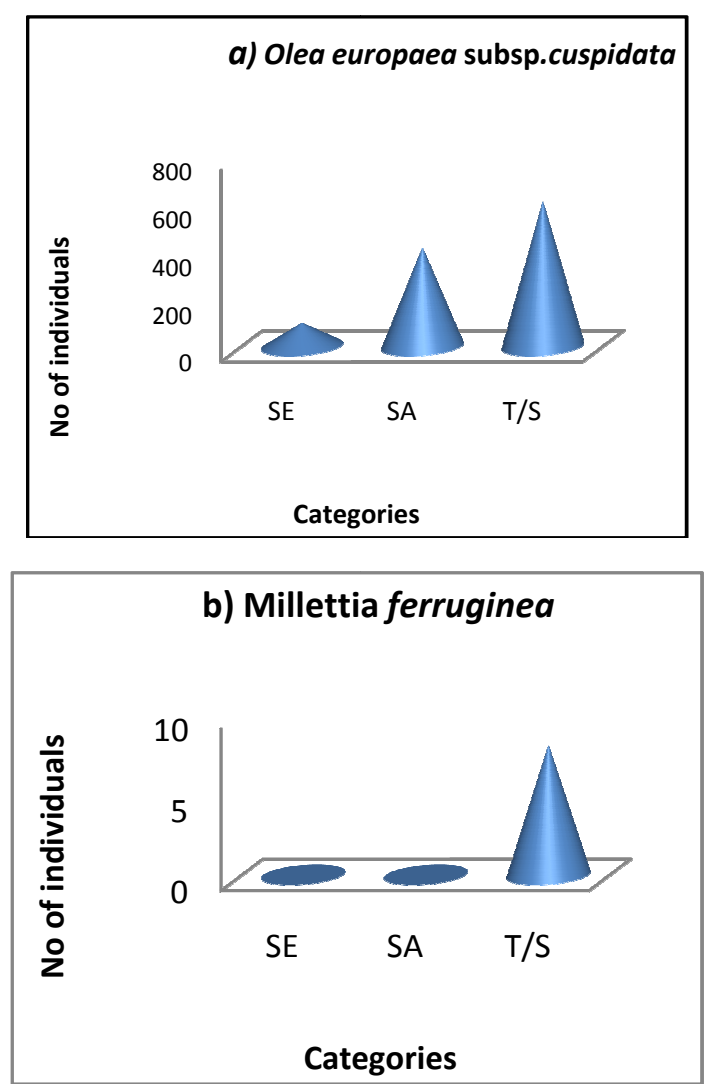

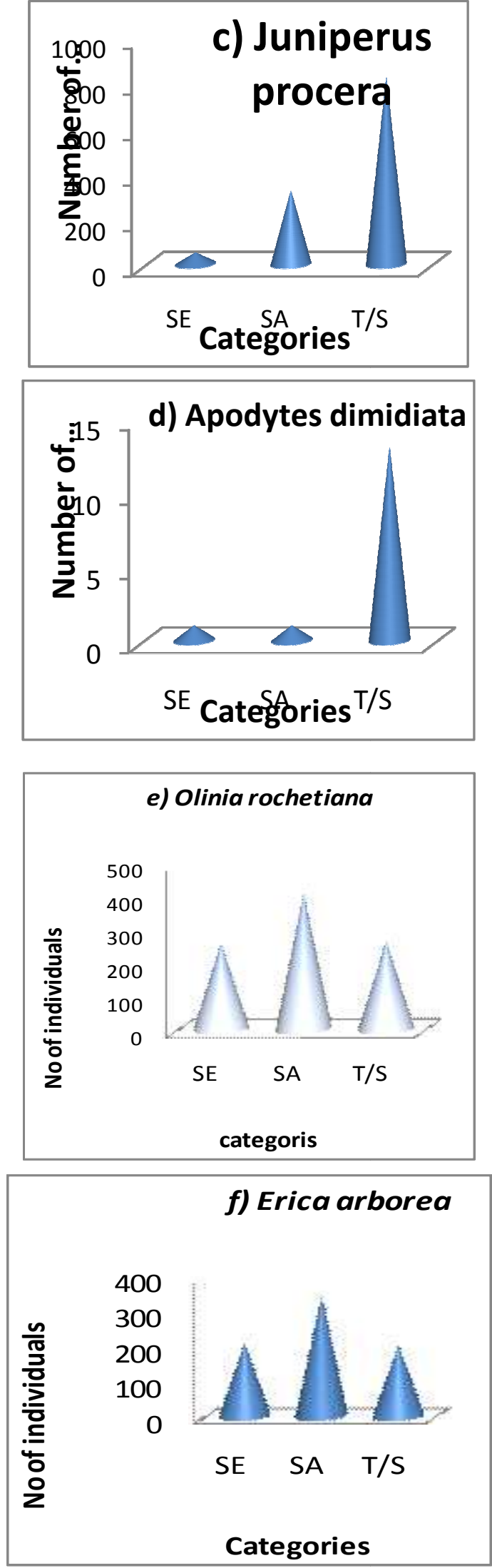

Figure 8. (a-f). Seedlings, saplings and tree/shrub distribution of some selected species occurring in MAMForest.
The second distribution pattern represents the highest population in sapling stages and medium in seedlings and trees. The pattern is represented by Olinia rochetiana, Rhus vulgaris and Erica arborea (Fig.8e and f). Few seedlings per species may be due to disturbances like seed predators, grazers, canopy cover for seedling recruitment, nature of seeds dormancy breakage in relation to environmental factors, physical factors, pathogens, and others those affecting the nature of propagation and reproduction.

Pattern three shows complete absence of seedlings and saplings. This includes Apodytes dimidiata and Millettia ferruginea and has very rare mature individuals in the forest (Fig.8b). The result from regeneration analysis of species revealed the complete absence or small amount distribution of seedlings and saplings shows insufficient recruitment hampered regeneration for the majority of species. This may be due to sensitiveness of seedlings and saplings to the disturbance such as seed predators, grazers and browsers, lack of safe site for seedling recruitment, litter accumulation, pathogens and environmental variables.

To set priority for regeneration analysis species in the study site, the species were classified in to three groups. Group 1, those species that were totally absent in regeneration category, Group 2, species whose density was greater than zero and less than 50 individuals $\mathrm{ha}^{-1}$ and Group 3 , species having individuals greater than 50 individuals ha ${ }^{-1}$ (Table 4).

Table 4. List of species under regeneration status group.

\begin{tabular}{lll}
\hline Regeneration status & \\
\hline Group 1 & Group 2 & Group 3 \\
\hline & Arundinaria alpina & Acacia abysinica \\
& Buddleja polystachya & Bersama abyssinica \\
& Croton macrostachyus & Carissa spinarum \\
& Ekebergia capensis & Podocarpus falcatus \\
& Ficus sur & Dombeya torrida \\
& Hagenia abysinica & Dovyalis abysinica \\
& Maesa lanceolata & Erica arborea \\
dimidiata & Maytenus obscura & Hypericum revolutum \\
ferruginea & Ryrica salicifolia & Juniperus procera \\
& & Maytenus arbutifolia \\
& & Nuxia congesta \\
& & Olea europaea subsp. \\
& & cuspidata Olinia rochetiana \\
& & Osyris quadripartita \\
& & Pittosporum viridiflorum \\
& & Scolopia theifolia \\
& & Prunus africana \\
& Rhus glutinosa \\
& Rhus vulgaris \\
& & Sideroxylon oxyacanthum \\
& &
\end{tabular}

Species classified as Group 1 and Group 2 is recommended to be given the highest priority for conservation purpose. The result shows certain gaps between floristic composition and structure of matured stands and the regeneration. Some of the matured trees lacked seedlings and /or saplings. This suggests that their regeneration from 
seedling and sapling is reduced and these species may disappear in the future. Abundance of seedlings and saplings are indicators of the establishment of young individuals. The regeneration potential of plant species could depend on factors like soil seed bank, physical factors and anthropogenic activities.

\section{Conclusion}

Result of the present study revealed that most tree species were in poor regeneration and recruitment level. The total density of tree stems per hectare was 4362.08 indicating that the vegetation of the Forest has densely populated and dominant trees like Juniperus procera, Olea europaea subsp. cuspidata, Olinia rochetiana and Rhus vulgaris. The species population structure showed different dynamics. Most species have high population in the lower DBH and Height classes. Few species occur in all DBH and Height classes showing variation in population size. The forest is characterized by high density of trees in the lower class than in the higher. The total Basal Area of trees whose DBH $>2.5$ $\mathrm{cm}$ was $84.17 \mathrm{~m}^{2} \mathrm{ha}^{-1}$. This value is supposed to be high in basal area coverage in dry evergreen montane forest. IVI of $59.14 \%$ was attributed by Juniperus procera, Olea europaea subsp. cuspidata, Podocarpus falcatus, Olinia rochetiana, Erica arborea and Rhus vulgaris. These species were also important in ecological significance. Species classified as regeneration classes as Group 1 (with no regeneration like Apodytes dimidiata and Group 2 (>zero \& <50) individuals $\mathrm{ha}^{-1}$ as Millettia ferruginea, Hagenia abyssinica, Ficus sur, Ekebergia capensis, Maytenus obscura, Croton macrostachyus, Maesa lanceolata, Buddleja polystachya, Rhamnus staddo and Myrica salicifolia) are recommended to be given high priority for conservation purpose.

\section{References}

[1] Bekele, T. (1993) Vegetation Ecology of Remnant Afromontane Forests on the Central Plateau of Shewa, Ethiopia. Acta Phytogeogr. Suec. 79:1-59.

[2] Bekele, T. (1994) Comprehensive Summaries of Uppsala Dissertations from the Faculty of Science and Technology: Studies on Remnant Afromontane Forest on the Central Plateau of Shewa, Ethiopia. Acata Universities Upsaliensis, Uppsala.

[3] Chaffey, D.R. (1979) Southwest Ethiopia Forest Inventory Project, a Reconnaissance Inventory of Forest in Southwest Ethiopia. Land Resources Development Centre, Tolworth Tower Surbition Survey, England.

[4] Coetzee, J.A. (1978) Phytogeogarphical aspects of the montane forests of the chain of mountains on the eastern side of Africa. Erdwiss Forsch. 11: 482-494.

[5] Demissew, S. (1980) A study on the structure of a montane forest. The Menagesha-Suba State Forest. Unpublished M.Sc Thesis, Addis Ababa University, Addis Ababa.
[6] Demissew, S. (1988) The Floristic composition of the Menagesha State Forest and the Need to Conserve Such Forest in Ethiopia. Mount. Res. Devt. 8: 243-247.

[7] Denu, D. (2007) Floristic composition and ecological study of Bibita forest (Gurda Farda), southwest Ethiopia, Unpublished MSc Thesis, Addis Ababa University, Addis Ababa.

[8] Eshete, A., Teketay, D. and Hulten, H. H. (2005) The SocioEconomic Importance and Status of Populations of Boswellia papyrifera (Del.) Hochst in Northern Ethiopia: The Case of North Gondar Zone. Forests Trees and Livelihoods, 15: 55-74.

[9] Friis, I. (1986) The forest Vegetation of Ethiopia. Acta Univ. Ups. Symb. Bot. Ups XXVI: 31-47.

[10] Friis, I. (1992) Forest and Forest trees of North East Tropical Africa. New Bulletin, Additional series, XV: 1-396.

[11] Friis, I. and Tadesse, M. (1990) The evergreen forests of tropical Northeast Africa. Mitt. Inst. Allg. Bot. Hamburg. 23a: 249-263.

[12] Friis, I., Rasmussen, F.N. and Vollesen, K. (1982) Studies in the flora and vegetation of Southwest Ethiopia. Opera Botanica 63: 8-70.

[13] Gebre Egziabher, T.B. (1986) Ethiopian vegetation - past, present and future. SINET: Ethiop. J. Sci. 9: 1-13.

[14] Gebre Egziabher, T.B. (1988) Vegetation and environment of the mountains of Ethiopia: implications for utilisation and conservation. Mount. Res. Dev. 8: 211-216.

[15] Gebre Egziabher, T.B. (1991) Diversity of Ethiopian flora. In: Plant Genetic Resources of Ethiopia, pp. 75-81, (J.M.M Engels, J.G. Hawkes \& Melaku Worede, eds.) Cambridge University Press, Cambridge.

[16] Gilbert, E.F. (1970) Mount Wachacha: A botanical Commentary. Walia 2: 3-12.

[17] Goldsmith, F. B., Harrison, C. M. and Morton, A. J. (1986) Description and analysis of vegetation. In: Methods in Plant Ecology, (Moore, P.D. and Chapman, S. B. eds). Black Well Scientific Publications, Oxford. Pp. 437- 515.

[18] Greig-Smith, P. (1983) Quantitative Plant Ecology (3 ${ }^{\text {rd }}$ ed.). Butterworths, London.

[19] Grub, P.J., Lloyd, J. R., Pennington, J. D. \& Whitmore, J.C. (1963). A comparison of montane and lowland rain forest in Ecuador. I. The forest structure, physiognomy and floristics.

[20] Haugen, T. (1992) Woody vegetation of Borana, South Ethiopia, a study on the main vegetation types of the area. SINET: Ethiopi. J. Sci. 15: 117-130.

[21] Hedberg, O. (1951) Vegetation belts of the East African Mountains. Sven. Bot. Tidskr. 45:140-204.

[22] Hedberg, O. (1957) Afroalpine vascular plants, a taxonomic revision. Symbolae Botanicae Upsaliensis 15 (1): 1-411.

[23] Hutchings, M. J. (1986) Plant population biology. In: Methods in Plant Ecology, (Moore, P. D. and Chapman, S. B. eds). Black Well Scientific Publications, Oxford. pp.377- 435.J. Ecol. 51: 567-610.

[24] Kent, M and Coker, P. (1992) Vegetation Description and Analysis. A practical approach. Bolhaven Printing Press, London. John Wiley and Sons. Inc. New York. pp 547. 
[25] Lamprecht, H., (1989) Silviculture in the tropics Tropical forest ecosystem and their tree species, Possibilities and methods for their long-term utilization. T2 Verlagsgesselschaft GmbH, Postatch 1164, D101 RoBdort, Republic of Germany Pp 290-296.

[26] Miehe, G. and Miehe, S. (1994). Ericaceous Forests and Heath lands in the Bale Mountains of South Ethiopia: Ecology and man's Impact. Stiftung Walderhaltung in Africa, Hamburg.

[27] Mooney, H.F. (1963). An account of two journeys to the Araenna Mountains in Bale province (Southeast Ethiopia), 1958 and 1959-1960. Proc. Linn. Soci. 172: 127-147.

[28] Mueller-Dombois, D. and Ellenberg, H. (1974). Aims and Methods of Vegetation Ecology.

[29] Pichi-Sermolli, R.E.G. (1957) Una carta geobotanica dell' Africa Orientale (Eritrea, Etiopia, Somalia). Webbia 13: 15132.

[30] Shannon, C.E. and Wiener, W. (1949). The Mathematical Theory of Communication. University of Illinois, Chicago, USA.

[31] Sharew, H. (1982) An Ecological Study of a Forest in Jemjem in Sidamo. MSc Thesis, Addis Ababa University, Addis Ababa. Unpubli.

[32] Shibru, S. and Balcha, B. (2004) Composition, structure and regeneration status of woody species in Dindin Natural Forest, Southeast Ethiopia; An implication for conservation. Ethiopian Journal of Biological Science 3:15-35.

[33] Soromessa, T. and Demissew, S. (2002) Some uses of plants by the Benna, Tsemay and Zeyise people, southern Ethiopia. EJNR 4 (1): 107-122.

[34] Soromessa, T., Teketay, D. and Demissew, S. (2004) Ecological study of the vegetation in Gamo Gofa zone, southern Ethiopia. Tropical Ecology 45: 209-221.

[35] Tadesse, M. (1992) A survey of the evergreen forests of Ethiopia. NAPRECA Monograph Series No. 2: 1-18.

[36] Teketay, D. (2001) Deforestation, Wood Famine, and Environmental Degradation in Ethiopia's Highland Ecosystems: Urgent Need for Action. Forest Stewardship Council (FSC Africa), Kusami, Ghana. Northeast African Studies 8: 53-76.

[37] Uhlig, S.K. (1988) Mountain forests and upper tree limit on the southeastern plateau of Ethiopia. Mount. Res. Dev. 8: 227234.
[38] Uhlig, S.K. and Uhlig, K. (1990) The floristic composition of a natural montane forest in southeastern Ethiopia. Feddes Repert. 101: 227-234.

[39] Van der Maarel, E. (1979). Transformation of cover abundance values in phytosociology and its effects on community. Vegetatio 39: 97-114.

[40] Von Breitenbach, G. (1961). Forests and woodlands of Ethiopia, a geobotanical contribution to the knowledge of the principal plant communities of Ethiopia, with special regards to forestry. Ethiop. For. Rev. 1: 5-16.

[41] Von Breitenbach, G. (1963). Indigenous Trees of Ethiopia. Ethiopian Forestry Association, Addis Ababa.

[42] Westphal, E. (1975). Agriculture in Ethiopia. Addis Ababa/Wageningen (College of Agriculture, Haileselassie I University and the center for agricultural publication and documentation. Wageningen Agricultural University).

[43] Woldu, Z. (1985) Variation in grassland vegetation on the central plateau of shewa, Ethiopia in relation to edaphic factors and grazing conditions. Doctoral thesis, Uppsala University Dissertations Botanicae, 84, J.Cramer,Vaduz.

[44] Woldu, Z. and Backeus, I. (1991) The Shrubland Vegetation in Western Shewa, Ethiopia and its Possible Recovery. J. Veg. Sci. 2: 173-180.

[45] Woldu, Z., Feoli, E. and Nigatu, L. (1989) Partitioning an elevation gradient of vegetation from southeastern Ethiopia by probability methods. Vegetation 18:189-198.

[46] Yeshitela, K. and Bekele, T. (2003)The woody species composition and structure of Masha-Anderacha forest, Southwestern Ethiopia. Ethiop. J. of boil. Sci.. 2 (1):32-48.

[47] Zewdie, A. (2007) Comparative Floristic study on Menagesha-Suba State Forest on Years 1980 and 2006, Unpublished M.Sc. Thesis, Addis Ababa University, Addis Ababa.

[48] Muluken Mekuyie Fenta. Human-Wildlife Conflicts: Case Study in Wondo Genet District, Southern Ethiopia. Agriculture, Forestry and Fisheries. Vol. 3, No. 5, 2014, pp. 352-362. doi: 10.11648/j.aff.20140305.14

[49] Siboniso M. Mavuso, Absalom M. Manyatsi, Bruce R. T. Vilane. Climate Change Impacts, Adaptation and Coping Strategies at Malindza, a Rural Semi-Arid Area in Swaziland. American Journal of Agriculture and Forestry. Vol. 3, No. 3, 2015, pp. 86-92. doi: 10.11648/j.ajaf.20150303.14 